\title{
Do silêncio e do seu imaginário. A Book of Silence (Um livro do Silêncio), de Sara Maitland, sob interrogação
}

\author{
Silence and its imaginary. A Book of Silence, de Sara Maitland, under \\ interrogation
}

\author{
Alberto Filipe Araújo * \\ Ángel García del Dujo**
}

Resumo

\begin{abstract}
O presente estudo parte da obra de Sara Maitland, intitulada A Book of Silence (Um Livro do Silêncio) e procura refletir sobre esse tema na linha da alta espiritualidade cruzando-o com as figuras do imaginário que enformam o próprio silêncio. Com esta finalidade, procuramos na primeira parte, dedicada ao silêncio, compreender a natureza do silêncio, nas suas manifestações, tipos e imagens, tal como ele foi pensado e analisado por Sara Maitland na sua obra O Livro do Silêncio. Em seguida, numa segunda parte, refletir sobre o significado dessa constelação de imagens para tentarmos delinear o imaginário do silêncio. Na terceira parte, tendo já em conta os desenvolvimentos das primeira e segunda partes, refletiremos sobre a trilogia do silêncio-imaginário-criatividade. Concluiremos com algumas reflexões e interrogações suscitadas pela análise da obra da autora.
\end{abstract}

Palavras-chave: Silêncio. Imaginário. Livro do Silêncio. Sara Maitland. Espiritualidade.

\begin{abstract}
The present study is based on the work by Sara Maitland entitled A Book of Silence and seeks to reflect on this theme in the line of high spirituality by crossing it with the figures of the imaginary that form the silence itself. To this end, we seek in the first part, devoted to silence, to understand the nature of silence in its manifestations, types and images, as it was thought and studied by Sara Maitland in her A Book of Silence. Then, in the second part, reflect on the meaning of this constellation of images to try to delineate the imaginary of silence. In the third part, taking into account the developments of the first and second parts, we will reflect on the trilogy of silence-imaginary-creativity. We will conclude with some reflections and questions raised by the analysis of the author's work.
\end{abstract}

Keywords: Silence. Imaginary. Book of Silence. Sara Maitland. Spirituality.

Artigo submetido em 02 de fevereiro de 2017 e aceito em 24 de abril de 2018.

Este trabalho é financiado pelo CIEd - Centro de Investigação em Educação, projetos UID/CED/1661/2013 e UID/CED/1661/2016, Instituto de Educação, Universidade do Minho, através de fundos nacionais da FCT/MCTES-PT.

\footnotetext{
* Doutor pela Universidade do Minho. Atualmente, é professor catedrático da Universidade do Minho e membro integrado do Centro de Investigação em Educação (CIEd) do Instituto de Educação da Universidade do Minho. País de origem: Portugal. E-mail: afaraujo@ie.uminho.pt

** Doutor em Ciências da Educação pela Universidade de Salamanca (Espanha) e Doutor Honoris Causa pela Universidade Nacional Mayor (Perú). Professor Catedrático da Faculdade de Educação da Universidade de Salamanca. País de origem: Espanha. E-mail: agd@usal.es
} 


\section{Introdução}

Numa sociedade onde o ruído e a palavra se tornaram omnipresentes tratar do tema do silêncio pode parecer, à primeira vista, estranho senão mesmo exótico. No entanto, o silêncio é um tema universal, arquetipal ou arquetípico, diria Carl Gustav Jung, que nunca deixou de ser tratado ao longo do século $\mathrm{XX}^{2}$, ganhando mesmo neste início do século XXI uma atenção considerável3.

A leitura da autobiografia do silêncio vivido e experienciado por Sara Maitland deu origem a um livro, ao qual ela chamou A Book of Silence (2008)4, onde escreveu:

Pareceu-me extremamente assustador descobrir que o silêncio era tão complexo e exigia de mim uma resposta a questões difíceis. Mas também o achei fascinante e profundamente envolvente. [...] Se podem existir diferentes dimensões de infinidade, é evidente que também é possível encontrar diferentes volumes de silêncio; e, na verdade, agora espero que possa haver sinfonias completas de silêncio. (MAITLAND, 2011, p. 256, p. 257).

Já no final da obra, particularmente no capítulo 8 - A Chegada a Casa, escrevia Sara Maitland que o silêncio é aquilo que mais desejava. Pretendia que ele fosse real, factual e estruturado. Por outras palavras, queria senti-lo, vivenciá-lo, mesmo saboreá-lo sensitivamente e não transformá-lo num mero estado de espírito abstrato, filosófico ou espiritual, como muitas vezes acontece, quando se começa a escrever sobre o assunto (MAITLAND, 2011, p. 381). Admitindo, ainda, que seja próprio da natureza do silêncio resistir "a todas as tentativas de falar sobre ele, tentar teorizá-lo, explicá-lo, ou até mesmo descrevê-lo” (MAITLAND, 2011, p. 45), nós, pelo nosso lado, erigimo-lo como um dos temas angulares da vivência humana e da alta espiritualidade. Não se trata aqui de refletirmos sobre um silêncio qualquer ou circunstancial, mas antes do silêncio interior que é um silêncio

\footnotetext{
${ }^{2}$ Consulte-se, por exemplo, a seguinte bibliografia sobre o silêncio organizada, em 2014, por Claudia Antognini da Biblioteca Cantonale di Bellinzona (Suiça), in: http://www.sbt.ti.ch/bcb/silenzio/documenti/bibliografia.pdf.

${ }^{3}$ Leiam-se, por exemplo, os estudos do Cardinal Robert Sarah e Nicolas Diat, Michel Maffesoli, Alain Corbin, entre outros.

${ }^{4}$ Permitimo-nos chamar a atenção para a alteração do artigo na tradução portuguesa: 0 Livro do Silêncio enquanto na versão original em inglês lê-se A Book of Silence. Trata-se, a nosso ver, de uma alteração que dá por si que pensar e que escrever. Eis aqui, portanto, um novo desafio futuro.
} 
espiritual. Um tipo de silêncio coberto pelo seu véu impenetrável que a palavra tem que saber romper, mas sobretudo merecer romper: "A palavra deseja quebrar o silêncio; essa é a sua tarefa” (MAITLAND, 2011, p. 168). A palavra proclamada tem que ser merecedora de irromper através da densidade do silêncio que parece, lembrando John Cage na sua composição 4'33”, datada de 1952, ouvir-se quando não há nada para escutar: "Comecei a sentir pela primeira vez aquela misteriosa ‘canção' ou ‘som do silêncio”" (MAITLAND, 2011, p. 267, p. 44-45, p. 88-89, p. 267268). A densidade do silêncio nem sempre está à espera de ser estilhaçada pela linguagem porque acontece que, tantas vezes, ela, através da morte, anuncia a presença do silêncio eterno como um “enorme e cálido nada” (MAITLAND, 2011, p. 267).

O dito não significa, contudo, que assim como há palavras e Palavra também há silêncios e Silêncio. Se nem todas as palavras se equivalem, o mesmo é igualmente válido para os silêncios: há silêncios emocionalmente diferentes e também os há intelectualmente diferentes. O silêncio de per se não é necessariamente fértil à semelhança da palavra proferida, ele somente o é, só se revela enorme, vasto e eterno quando imita a grandeza incomensurável do silêncio das estrelas e daquilo que está para além do céu estrelado ou enevoado.

No entanto, aquilo que procuramos na obra de Sara Maitland, dedicada ao silêncio, mais do que definições ou abordagens reflexivas que serão, aliás, consideradas, é recensear as imagens que a autora associa ao silêncio, tais como as do deserto, do voo das aves, das ilhas, enfim, das profundezas traduzidas pela metáfora do buraco negro. Não se trata só de elencarmos essas constelações de imagens que nos desenham o imaginário do silêncio, mas de refletirmos especialmente sobre o que essas mesmas imagens significam e contribuem para uma ontologia do silêncio. Neste contexto, consideramos pertinente esclarecer que, metodologicamente, abordaremos o presente trabalho do ponto de vista da hermenêutica simbólica, particularmente da hermenêutica durandiana, que 
confere um valor semântico às imagens (DURAND, 1984)5. Analisaremos a obra de Sara Maitland por ela mesma, enquanto fonte de inspiração para a nossa narrativa, mas também seremos fiéis àquelas passagens que focam explicitamente as várias imagens do silêncio.

Do ponto de vista da estruturação do presente estudo ele será constituído por três partes. Na primeira parte, dedicada ao silêncio, procuraremos compreender a natureza do silêncio, nas suas manifestações, tipos e imagens, tal como ele foi pensado e analisado por Sara Maitland na sua obra $O$ Livro do Silêncio. Em seguida, numa segunda parte, refletiremos sobre o significado da constelação de imagens, elencada pela própria autora, para tentarmos delinear o imaginário do silêncio. Este será o nosso propósito, ainda que igualmente admitamos que a obra de Sara Maitland possa ser objeto de outro tipo de leituras, por exemplo, encará-la como se fosse um romance de formação (Bildungsroman), no qual a iniciação da própria autora ao silêncio desempenharia um papel crucial na sua trans-formação (Umbildung). Na terceira parte, tendo já em conta os desenvolvimentos das primeira e segunda partes, refletiremos sobre a trilogia do silêncio-imaginário-criatividade. Concluiremos com algumas reflexões e interrogações suscitadas pela análise da obra de Sara Maitland.

\section{Do silêncio}

O silêncio como tema humano universal representa uma força antropológica, ontológica ética e educacional de longo alcance (MAITLAND, 2011, p. 239). A força do silêncio transborda a sua mera dimensão intelectual para se afirmar mais como um silêncio íntimo e de pudor. Este tipo de silêncio nunca pode ser obrigatório ou imposto, antes tem que ser desejado e merecido, isto é, conquistado por todo aquele ou aquela que, insurgindo-se contra a ditadura do ruído, a ele se abre voluntariamente. É, pois, um silêncio desejado, oposto,

\footnotetext{
${ }^{5}$ A este respeito, Gilbert Durand salienta o seguinte: "nós partimos de uma concepção simbólica da imaginação, quer dizer de uma concepção que postula o semantismo das imagens, o facto que elas não são signos, mas contêm materialmente de algum modo o seu sentido" (DURAND, 1984, p. 60), e "a imagem simbólica é semântica: quer dizer que a sua sintaxe não se separa do seu conteúdo, da sua mensagem" (DURAND, 1984, p. 457). Ver, igualmente, o cap. IV. - Mitos e Semantismo, p. 410-433, das Les Structures Anthropologiques de L'Imaginaire, de Gilbert Durand.
} 
portanto, ao silêncio imposto que é sempre terrível senão mesmo letal. Todo o silêncio desejado implica sempre um processo longo, delicado e disciplinado, de busca interior, de trabalho íntimo, mesmo de disciplina, quase que heroica, sobre as emoções fortes, vividas em silêncio, a par de diálogos interiores fortes.

\subsection{Manifestações do silêncio}

Na ilha de Skye, situada na Escócia, mais precisamente numa casa isolada, chamada Allt Dearg, à sombra dos montes Cuillin (MAITLAND, 2011, p. 59-60), uma antiga cabana de pastores, Sara Maitland viveu a sua experiência de aprendizagem do silêncio, relatada no segundo capítulo do seu livro, ao qual deu o nome de "Quarenta Dias e Quarenta Noites" (MAITLAND, 2011, p. 54-114, p. 58). A sua estadia correspondia, diríamos, à fase de noviciado das ordens religiosas:

Fascinada pelo silêncio, alegremente atraída para o vazio, eu queria viver a versão completa; queria saber realmente o que era aquilo que tentava construir na minha vida antes que os hábitos do quotidiano se afirmassem. [...] Queria explorar o que poderia significar este impulso profundo em direção ao silêncio. Queria examinar a minha convicção de que o silêncio era algo de positivo, e não apenas uma abstração ou ausência. Queria saber o que iria acontecer. (MAITLAND, 2011, p. 58).

Durante o período de quarenta dias, que a autora viveu em Skye, registou, pelo menos, oito experiências distintas de silêncio que sintetizou do seguinte modo:

uma intensificação tanto da sensação fisiológica como da sensação psicológica; uma sensação de 'oferenda' ou de ligação; alucinações auditivas - audição de vozes de um género muito particular; confusões com as delimitações; uma consciência divertida de estar em risco, em perigo; inefabilidade e bênção. (MAITLAND, 2011, p. 113, p. 73-130).

Referindo-se ao seu estado de espírito face à sua experiência silenciosa, que durou seis semanas, Sara Maitland descreve-o como

uma das coisas mais significativas que jamais fizera na vida. Fora interessante, exigente, excitante, divertido e profundamente alegre. Serviu para conferir essência às minhas escolhas e à minha vida desde então. Tenho-me empenhado em tentar desenvolver essas experiências, 
transformando-as num estilo de vida diário e sustentável. Skye é simultaneamente um marco e um ponto de partida para grande parte da minha vida presente. (MAITLAND, 2011, p. 114).

No capítulo terceiro, a autora fala-nos do "lado obscuro" do silêncio, escrevendo que:

É tudo muito positivo e glorioso, contudo vivemos numa sociedade que sabe que o silêncio é perigoso. [...] Enquanto sociedade, fazemos todos os possíveis para evitar o silêncio a todos os níveis. O silêncio é aterrador, artificial e leva as pessoas à loucura. Alegadamente, o silêncio é muito obscuro, muito pesado. (MAITLAND, 2011, p. 115).

Admite, contudo, que quando do seu regresso a Weardale sentiu que havia perdido alguma coisa, pois "não tinha descoberto totalmente o prometido 'lado obscuro' do silêncio" (MAITLAND, 2011, p. 115). Relatou apenas uma experiência assustadora ligada ao silêncio sintetizada pelo oxímoro de "ouvir o silêncio a gritar" (MAITLAND, 2011, p. 117) ao ponto que parecia que o silêncio a desnudava, a secava, a despojava. "Julgava ouvir o próprio silêncio a gritar" (MAITLAND, 2011, p. 117). A situação de silêncio radical vivida pela autora desencadeou algo mais que um mero ataque de pânico, algo que ela classificou de "muito mais primitivo" (MAITLAND, 2011, p. 118), que mitologicamente recebia o nome do deus Pã (MAITLAND, 2011, p. 118). Apesar deste tipo de sensação, contudo, ela não refletiu nem as expetativas de Sara Maitland de "horror sublime" (MAITLAND, 2011, p. 119), nem a possibilidade de ficar louca: "Ninguém que parta em busca do silêncio pode esperar que ele seja simples ou direto: é necessariamente complicado e, segundo todos os relatos, pode levar à insanidade" (MAITLAND, 2011, p. 119). Sara apenas desejava "viver a totalidade do silêncio. Queria compreender Donald Crowhurst, assim como Bernard Moitessier - a desintegração obscura, o enorme vazio, os demónios dos eremitas do deserto" (MAITLAND, 2011, p. 120).

Aconteceu que devido a condições atmosféricas muito adversas, a autora ficou isolada do mundo ao ponto de ter escrito que: "O silêncio esvaziava-me e deixava-me oca e nua" (MAITLAND, 2011, p. 121), especialmente quando ouviu, ao longo da sua caminhada, "ruídos de choro mais agonizantes que jamais escutara - 
naquele momento, parecia-me ser o choro dos condenados" (MAITLAND, 2011, p. 122). Porém, para seu grande alívio, identificou rapidamente a fonte donde provinha esse "choro” (MAITLAND, 2011, p. 122), porque, se não o tivesse feito, poderia ter enlouquecido: "Consigo perceber muito facilmente como este género de silêncio pode levar alguém a entrar em pânico e a cair num estado de verdadeira loucura” (MAITLAND, 2011, p. 123, p. 135-136, p. 152). Neste contexto, escreveu que as suas experiências negativas do silêncio foram pequenas, mas permitiram, todavia, compreender um pouco “como o silêncio pode ser esmagador e destruidor, e como os terrores parecem seguir de perto os mesmos caminhos e padrões das alegrias" (MAITLAND, 2011, p. 123).

A este respeito, narrando a aventura do alpinista Simpson, refere que o seu silêncio involuntário e curto traduziu-se por uma experiência muito intensa, dizendo que ela

contém, de uma forma intensificada, muitos dos efeitos do silêncio negativo: além da audição de uma voz, ele caiu em padrões de comportamento ritualistas e confusos; perdeu o sentido normal do tempo; passou por variações de estado de espírito loucas e ficou gradualmente sem controlo sobre a sua mente. (MAITLAND, 2011, p. 144).

Se acontece alguém não ter escolhido o silêncio de uma forma livre e convicta, ele acaba por ter consequências negativas, quer para a pessoa, quer para o seu entorno. Aquele que abraça o silêncio, ainda que de modo involuntário, vê-se confrontado com consequências sombrias de difíceis contornos tanto mais que ele pode ser assumido como uma reclusão ou não. Pelo contrário, o silêncio revela-se positivo se foi escolhido livremente e este aspeto, nunca é demais sublinhar, marca a diferença. O valor positivo do silêncio, como libertador, acolhedor e generoso, não implica somente uma ausência de som, mas antes toda uma preparação espiritual em ordem à meditação e à contemplação: "O silêncio zen é um silêncio positivo. Ficamos silenciosos para escapar à personalidade e aos dualismos do mundo, para 'protestar' contra os véus da ilusão e transcendê-los” (MAITLAND, 2011, p. 193). Nesta linha, Sara Maitland relata o seu ataque de acédia e cujas caraterísticas predominantes são as seguintes: “a falta de afecto, uma sensação 
terrível de vazio e um aborrecimento estranhamente inquieto e insatisfeito" (MAITLAND, 2011, p. 153, p. 153-161) que transformou as suas alegrias devidas ao silêncio em algo de amargo (MAITLAND, 2011, p. 153).

No entanto, a autora admite que aquilo que aprendeu sobre o silêncio, para o melhor e para o pior, reconfortava-a bastante e, no fundo, era isso que ela pretendia. $\mathrm{O}$ que realmente pretendia era aprender o hábito do silêncio, tanto interna como externamente, o que passava necessariamente por disciplinar-se a si e à sua família e seus amigos: "aquilo que eu queria, desenvolver e manter um padrão disciplinado de meditação e oração, desligar o telefone, viver a vida devagar, caminhar, observar, ouvir o silêncio” (MAITLAND, 2011, p. 163).

Aprender a viver no silêncio e com o silêncio revelou-se para ela uma experiência iniciática profunda e, num primeiro momento, profundamente perturbadora na medida em que nascemos virados para a palavra, para a luz e para a vida (regime diurno do imaginário, segundo a classificação de Gilbert Durand), enquanto o silêncio simboliza antes a escuridão e a morte (regime noturno do imaginário, segundo a classificação de Gilbert Durand). Daí o medo e o terror ctónico que o silêncio destila e inspira:

Agora o Terror abstrato assenta na ideia de que o silêncio virá a devorar as palavras - virá a soterrar completamente o significado, a reinstalar o vazio, e a luz apagar-se-á e todos nós vamos morrer; e os mortos são extremamente silenciosos. [...] negamos a realidade do silêncio, reduzimolo a uma falta ou a uma ausência, e retiramos-lhe todo o seu poder. Afirmamos que o silêncio 'necessita' - e, portanto, está à espera - de ser quebrado: como um cavalo que precisa de ser 'domado'. Mas continuamos assustados. E o iminente desastre ecológico aprofunda o nosso receio de que um dia a ciência não conseguirá funcionar, a linguagem desfazer-se-á e a luz apagar-se-á. Sentimo-nos aterrorizados com o silêncio, pelo que procuramos encontrar-nos com ele o menos possível, mesmo que isso signifique perdermos experiências que sabemos serem boas, como, por exemplo, as crianças passearem sozinhas ou sem qualquer controlo pelo campo. Dizemos que o silêncio é uma falta de algo, um estado negativo. Negamos o poder e o significado do silêncio. Ficamos aterrorizados com o silêncio e, portanto, banimo-lo das nossas vidas. (MAITLAND, 2011, p. 181).

Sara Maitland insiste nesta dimensão do silêncio que, mais do que ser desconfortável, é antes uma realidade antropo-psicológica e ôntica que faz medo, 
que ameaça, enfim, que perturba. Uma perturbação que aterroriza, simbolizada pela floresta simultaneamente bela e obscura, porque mexe no irracional daquele que experiencia o silêncio, involuntariamente, ou até mesmo voluntariamente. A longa sombra da floresta selvagem assemelha-se ao longo manto do silêncio que para muitos representa uma lenta asfixia. Aliás, o silêncio na sociedade do ruído (MAITLAND, 2011, p. 181-187), que é a nossa, é encarado como "sinistro, desonesto e desdenhoso" (MAITLAND, 2011, p. 189). O silêncio na sociedade do ruído, diz a autora, é escorraçado, evacuado para bem longe precisamente por ele evocar, ora latente ora manifestamente, o terror e o pavor acima focados. Não obstante a atitude da sociedade do ruído face ao silêncio ser claramente hostil, tal não significa, contudo, que não "permanecem pequenas poças dele nas vidas da maior parte das pessoas, pausas na corrente do som, que elas valorizam bastante, ainda que normalmente não as designem como silêncio” (MAITLAND, 2011, p. 252). Contudo, o silêncio voluntário, e especialmente o involuntário, reveste-se na sociedade contemporânea, abafada no e pelo ruído, de aspetos negativos, senão mesmo muito negativos, porque quase sempre aparentado com sentimentos de destruição total, de luto, de tristeza e angústias profundas cujo símbolo bem poderia ser o túmulo encarnando a própria morte. Esta, e o silêncio que ela transporta, torna-se ensurdecedoramente insuportável aos olhos da nossa sociedade hedonista, materialista e ruidosa (MAITLAND, 2011, p. 359-361):

A própria morte é silêncio, que pode muito bem ser o motivo para pensarmos que o silêncio é a morte. De certo modo, a morte é o único silêncio. A maior parte das pessoas não é concebida em silêncio; no útero ele não existe, o que há é a constante pulsação cardíaca maternal, e somos levados a sentir uma contínua 'melodia' de borbulhar, agitação, palpitação e energia. Logo que nascemos somos incentivados a gritar, a produzir um ruído, a anunciar a nossa chegada. Mas na morte o silêncio infiltra-se e instala-se. A morte é um acontecimento físico muito concreto, pelo que o seu silêncio é também concreto e físico, mas torna-se ainda mais intenso devido ao silêncio emocional que está necessariamente presente. Todas as coisas que não foram ditas nunca o serão, para o bem ou para o mal. Os vivos têm de se calar; não há nada mais a dizer. (MAITLAND, 2011, p. 359).

Neste sentido, o silêncio não só é encarado como um déficit ou uma falta, uma ausência de som sob a forma de discurso ou de ruído, mas também como uma 
realidade psico-ôntica intangível experienciada em certas condições e momentos como um silêncio assustador. Contudo, o silêncio não se limita simplesmente à ausência, ainda que difusa, de som, mas vai muito mais longe do que esse epifenómeno porquanto ele possui qualidades específicas próprias.

\subsection{Do silêncio aos vários tipos de silêncio}

Sara Maitland escreve que o silêncio não é somente privação do som e da palavra, ou seja, vazio e destituído de sentido humano, enfim, uma desfiguração carnal e espiritual do humano. Ele é também esperança e sentido quer no plano pessoal, individual ou subjetivo, quer no plano mais universal e cultural:

O silêncio é uma falta, uma ausência, um vazio - o silêncio é a negação da linguagem e, portanto, do significado e da liberdade. No princípio, era a palavra. Continuo a ter a certeza de que isto está errado, mas não consigo identificar por que motivo. Tenho vindo a recolher e a experimentar muitas instâncias fortemente positivas do silêncio, momentos da experiência humana onde não existe linguagem, onde não se ouve ruído, mas onde claramente não há qualquer sensação de perda ou de deficiência. Não quero com isto referir-me simplesmente aos meus próprios "momentos felizes" de silêncio, mas a momentos culturais mais amplamente reconhecidos. (MAITLAND, 2011, p. 372).

O silêncio vive-se como uma experiência multifacetada que ora surpreende, ora assusta, daí podermos dizer que não é um mero fenómeno mental assaz complexo, mas também estranhamente emocional. O silêncio aparenta-se, em certa medida, com o sagrado por ser fascinante e tremendo e despertar naquele que o vivencia um sentimento ora de terror ora de espanto:

Cheguei à conclusão [escreve Sara Maitland] de que, apesar de o som poder ser predominantemente um fenómeno do cérebro, o silêncio é um acontecimento da mente. A experiência do silêncio está mais intimamente ligada à cultura, à expectativa cultural e, estranhamente, à linguagem do que a experiência do som. O silêncio por opção pode ser criativo e gerar autoconhecimento, integração e profunda alegria; ser silenciado (um silêncio da responsabilidade de uma outra pessoa e que nos é imposto) pode levar uma pessoa à loucura. É possível sentir o silêncio exterior sem qualquer noção do silêncio interior e, em alguns casos, o inverso. [...] $\mathrm{O}$ silêncio é multifacetado, um tecido densamente entrelaçado de muitos cordões e fios diferentes. (MAITLAND, 2011, p. 255). 
Sara Maitland, ensinada pelo silêncio, começara a ouvir melhor num primeiro momento para, num segundo momento, começar a ver e a observar melhor. Graças à sua vivência profunda do silêncio, aprendeu a escutar as suas entoações o que a levou a escrever que "Havia, e continua a haver para mim, algo de profundamente misterioso no facto de existirem tantos tipos diferentes de silêncio" (MAITLAND, 2011, p. 256).

É, pois, esta gama diversa de silêncios que vamos em seguida explorar seguindo o mesmo percurso da autora. Ela constatou que havia, na verdade, vários tipos diferentes de silêncio e que o silêncio, pelo contrário, não era nem uniforme, nem indiferenciado: "Quanto mais silêncios observava e mais lugares silenciosos visitava, mais me consciencializava de que havia fios densos e entrelaçados de silêncios diferentes" (MAITLAND, 2011, p. 254). O silêncio, nos seus diferentes matizes, pode ser puro-impuro, belo-medonho, calmo-assustador, alegre-solitário, profundo-superficial uniforme-serpenteado, diferenciado-indiferenciado, simplescomplexo, interior-exterior, monótono-agitado, entre outras oposições mais ou menos complexas. Mesmo ao nível físico natural constata-se também uma variedade grande de silêncios, como é o caso do silêncio da neve ser diferente do silêncio chuvoso ou do silêncio do Sol: “Alguns fenómenos naturais, apesar de silenciosos em si mesmos, têm tendência para produzir sensações de paz ou de satisfação em vez de receio e inefabilidade" (MAITLAND, 2011, p. 373, p. 325). A este nível, assiste-se a experiências auditivas do silêncio: "Isto acontece em parte porque praticamente nunca existe verdadeira e completamente silêncio, pelo menos dentro da atmosfera terrestre, mas também porque estes diversos silêncios têm conotações emocionais diferentes" (MAITLAND, 2011, p. 254-255). Para além da experiência puramente auditiva, existe ainda uma gama maior de silêncios; há os emocionalmente diferentes e também aqueles que são intelectualmente diferentes.

Não deixa de ser importante, desde já, sublinhar que a vivência, a experiência do silêncio está mais ligada à cultura e ao modo de vivê-la, à linguagem do que à mera audição do som. Deste modo, Sara Maitland diz-nos, num primeiro 
momento, que existe uma diferença entre o silêncio criativo e aquele que é imposto: o primeiro gera autoconhecimento, integração e profunda alegria enquanto o segundo desperta o seu contrário e, por conseguinte, conduz uma pessoa à loucura (MAITLAND, 2011, p. 255). Num segundo momento, distingue o silêncio interior e exterior: “É possível sentir o silêncio exterior sem qualquer noção do silêncio interior e, em alguns casos, o universo” (MAITLAND, 2011, p. 255). Já num terceiro momento pensou que poderia haver uma distinção entre o silêncio dos eremitas e o dos artistas criativos.

Antes de continuar a distinguir os vários tipos de silêncio, Sara Maitland escreve que sempre acreditou que o silêncio, especialmente o da "natureza", era propício para estimular a criatividade artística e a espiritualidade religiosa, contudo, não era isso que acontecia. Não obstante não deixou de indagar, de perscrutar, que outros tipos de silêncios existiriam para além daqueles já mencionados. Assim, constatou que havia mais duas espécies distintas de silêncio que exigiam técnicas diferentes:

\footnotetext{
Na oração, tentamos esvaziar-nos do ego, fazer sair aquilo que está dentro de nós, tornamo-nos permeáveis, translúcidos vazios, abertos ao transcendente, ao passo que no acto de criação artística precisamos do silêncio para concentrar toda a nossa capacidade, para enriquecer ou fortalecer o ego. (MAITLAND, 2011, p. 262, p. 283, p. 289, p. 322).
}

No capítulo sexto, dedicado aos Eremitas do Deserto, falando da disciplina heroica dos eremitas (MAITLAND, 2011, p. 289), observa que no cerne desta disciplina se encontra o silêncio. Mas que tipo de silêncio ou de silêncios? O primeiro, o externo, escapa "às pressões do social; depois, o interno, a paz do coração e da mente, que só poderia advir da oferta generosa da própria personalidade, apoiada em muito trabalho árduo” (MAITLAND, 2011, p. 289). Esta distinção leva Sara Maitland a admitir "que há uma certa diferença de intenções entre o silêncio budista e o silêncio cristão" (MAITLAND, 2011, p. 290). Também distingue o silêncio religioso ou eremítico do silêncio romântico que são aqueles que importa aqui destacar:

O silêncio religioso ou eremítico, não apenas na tradição cristã, mas também no budismo, é essencialmente de vazio interior - de 
esvaziamento do espírito e do corpo de todos os desejos, de se ser purgado e, portanto, ficar puro: uma espécie de vazio, uma tabula rasa, sobre o qual se pode inscrever o divino. É uma disciplina de auto-esvaziamento, ou, para usar uma expressão teológica, de quemose, de autoderramamento. Enquanto isso, o romantismo usa o silêncio com objectivos exactamente opostos: para suportar e fortalecer as delimitações da personalidade; para tornar uma pessoa menos permeável ao Outro; para afirmar o ego contra a idealização e as expectativas da sociedade; para permitir que um indivíduo estabeleça uma liberdade autónoma e tenha uma voz autêntica. Em vez de autoesvaziamento, procura o preenchimento. (MAITLAND, 2011, p. 337- 338).

Estes dois tipos de silêncio - o do deserto e o romântico - pela sua natureza conflituam. Deste modo, não é demais aprofundar as suas caraterísticas porque o silêncio do deserto ou eremítico tenta tornar a personalidade tão aberta quanto possível, enquanto o silêncio romântico tenta isolar a personalidade das influências externas (MAITLAND, 2011, p. 338):

- Silêncio do deserto ou eremítico:

a) Desenvolve uma noção de tempo como espaço;

b) É mais provável que sinta prazer na inefabilidade;

c) É mais provável que valorize a abertura e a humildade;

d) É mais provável que deseje a jouissance, a abertura infinita à eternidade;

- Silêncio romântico:

a) A noção romântica do tempo como narrativa;

b) Fazer um esforço de autoexpressão;

c) Resolução ou do encerramento, que são representados por uma obra de arte acabada.

Em seguida, Sara Maitland assinala ainda seis tipos de silêncio mais particulares: o psicanalítico positivo que parece permitir uma nova espécie de autoconhecimento e a recriação do todo e da integridade de cada indivíduo; o silêncio que acontece depois do ato sexual quando se está com a outra pessoa sem qualquer exigência ou necessidade; o silêncio da experiência mística na qual o silêncio se torna o conteúdo assim como o contexto, considerado inefável e, de algum modo, impossível de atrair para a linguagem; a euforia silenciosa que frequentemente precede os episódios psicóticos e até epilépticos; o silêncio provocado por certo tipo de leituras em que se cria uma comunicação equilibrada e o escritor de coração generoso abre o espaço de silêncio ao leitor atento, e os dois 
trabalham em conjunto para produzir significado ; e, por fim, o silêncio quando se ouve um determinado género de música - especialmente música instrumental (por oposição à da voz humana). Todos estes silêncios, na sua diversidade, têm como denominador comum conduzir todos aqueles que os experienciam sintam o sentimento de inefabilidade e de recriação em ordem ao seu autoconhecimento (MAITLAND, 2011, p. 373-374).

\section{Do Imaginário do Silêncio}

É no capítulo quinto, que intitula Lugares de Silêncio (MAITLAND, 2011, p. 211-256), da sua obra, que Sara Maitland inicia o desenho do imaginário do silêncio quando escreve sobre as nuvens e da sua natureza6: "Contudo, são mais uma das forças silenciosas que nos rodeiam, anunciando à sua passagem que o silêncio tem efectivamente significado, tem efetivamente uma forma e um objetivo, e algo para me ensinar” (MAITLAND, 2011, p. 217). As nuvens (sob o signo do ar) e outros fenómenos meteorológicos ocuparam as observações atentas da autora em Weardale, que a levaram a se interessar pela observação dos insetos (cita, por exemplo, as aranhas) e das flores.

\subsection{0 imaginário do voo}

No entanto, aquilo que realmente lhe interessou foi, ao longo das suas caminhadas em Weardale, contemplar as aves e o seu voo (MAITLAND, 2011, p. 218-226) como seres que "habitam os espaços do silêncio" (MAITLAND, 2011, p. 219):

Tal como referi no capitulo de abertura [Crescer num Ambiente de Ruído, pp. 11-53], sempre senti um profundo fascínio pelo ato de voar. Na minha imaginação, nos meus sonhos e na minha ficção, voar - as aves, os anjos, os dragões, as borboletas, as bruxas, livres e graciosos no ar silencioso tem sido uma imagem central de liberdade e alegria. [...] Este género de busca lenta e cuidadosa, num voo silencioso, é o género de voo com que

\footnotetext{
${ }^{6}$ Sobre a natureza das nuvens, veja-se Sara Maitland. O Livro do Silêncio, p. 217. Sobre a simbólica das nuvens, veja-se Gaston Bachelard, L'Air et les Songes, p. 239-254.
} 
sonho [refere-se ao voo de duas corujas-de-orelhas-curtas]. (MAITLAND, 2011, p. 221).

Além disso, a autora sublinha que identificar as aves que observava se assemelhava "a ouvir os silêncios e aprender a escutar as suas entoações" (MAITLAND, 2011, p. 218). Quando fala dos pássaros (sob o signo do ar) diz que eles são belos, rápidos e livres associando de imediato a imagem do voo ao sonho, aliás bem estudada por Gaston Bachelard (2004, p. 27-84) no livro L'Air et les songes, ao ponto de Sara Maitland afirmar:

Acabei por ficar a pensar que voar, na verdade, é uma das maiores desilusões da história da tecnologia. Durante séculos, os seres humanos sonharam e criaram mitos e histórias sobre o ato de voar [a autora cita o mito de Dédalo - p. 223]. [...] O voo livre é um dos temas mais comuns dos sonhos mais doces, tal como cair é um tópico frequente nos pesadelos. E, sim, aprendemos a voar; alcançamos o sonho e ele revelou-se nada mais do que pó e cinzas. Ironicamente, tudo aquilo que diz respeito ao voo dos seres humanos é a antítese do que sonhamos. [...] Abdiquei do sonho e passei a preferir observar os pássaros - e acabei por me sentir cada vez mais relutante em viajar de avião. (MAITLAND, 2011, p. 223-224).

Ligada à experiência do voo, a autora narra um episódio que viveu com o seu filho na praia com um papagaio de papel. O papagaio de papel manobrado pelo seu filho:

Parecia conseguir fazer tudo e mais alguma coisa - dançar, picar, elevarse, mergulhar, deslizar, virar-se, pairar. Era o voo como tinha sido efectivamente sonhado - simultaneamente debaixo de controlo e inteiramente livre; silencioso mas no maior silêncio; como um pássaro, mas domesticado na sua mão [na do filho]; gracioso, mas inclinado perante o vento. (MAITLAND, 2011, p. 225-226).

O simbolismo do voo implica o schème 7 da elevação e, como tal, é um símbolo vertical. Intimamente ligado ao voo encontra-se a asa, que representa já um “meio simbólico de purificação racional” (DURAND, 1984, p. 144). O voo, enquanto substantivo, é um dos componentes simbólicos da imaginação dinâmica

\footnotetext{
${ }^{7}$ É um conceito de Gilbert Durand que não tem tradução em português para designar "uma generalização dinâmica e afetiva da imagem, ele constitui a factividade e a não-substantividade geral do imaginário" (DURAND, 1984, p. 61). É anterior à imagem, corresponde a uma tendência geral dos gestos. Ele faz a junção entre os gestos inconscientes e as representações. Exemplos: à verticalidade da postura humana, correspondem dois schèmes: o da ascensão e o da divisão (visual ou manual); ao gesto de deglutição, correspondem os schèmes da descida (percurso interior dos alimentos) e do aconchego na intimidade (o primeiro alimento do ser humano sendo o leite materno, a amamentação).
} 
que corresponde à imaginação aérea com as qualidades que lhe estão associadas: ligeireza, clareza e vibração. O pássaro como símbolo é eclipsado pelo verbo voar: “A asa é o atributo de voar, não do pássaro ou do inseto" (DURAND, 1984, p. 145). O verbo voar está ligado à pureza, à luz e à elevação e representa tantas vezes o mecanismo psicológico da sublimação. Igualmente nos faz pensar também na flecha. Já Gaston Bachelard (2004, p. 84) salienta que na imaginação humana “seja uma transcendência da grandeza”. Com o mesmo autor sublinhamos que a altura é mais do que um símbolo: "Aquele que a procura, aquele que a imagina com todas as forças da imaginação que é o motor mesmo do nosso dinamismo psíquico, reconhece que ela é materialmente, dinamicamente, vitalmente moral" (BACHELARD, 2004, p. 81). O eixo vertical expressa simbolicamente os valores morais, e o voo, estando ligado à altura e à elevação, é uma metáfora axiomática para Gaston Bachelard (2004, p. 17). Corresponderia à metáfora viva de Paul Ricoeur, que como nada a explica ela tem a capacidade de tudo explicar: "quando se pretende vivê-las bem, senti-las, e sobretudo compará-las, damo-nos conta que elas possuem uma marca essencial e que elas são mais naturais que todas as outras" (BACHELARD, 2004, p. 17).

O voo, indissociável do ar, está ligado ao mito de Ícaro ${ }^{8}$ e exprime sentimentos de movimento, de liberdade, de superioridade, de poder ou de força: “O voo está relacionado com o espaço e com a luz; psicologicamente é um símbolo do pensamento e da imaginação” (CIRLOT, 2000, p. 468). O voo exprime também

um desejo de sublimação, de procura duma harmonia interior, de um ultrapassar dos conflitos. [...] A imagem do voo é um substituto irreal da acção que deveria ser empreendida. Não sabendo, ou não podendo, ou não querendo empreendê-la, pede-se a um sonho que a realize, ultrapassandoa. Entretanto, há razão para conferir ao activo do desejo e do sonho de voo o símbolo de uma ascensão no plano do pensamento ou da moralidade; mas duma ascensão mais imaginária e passageira do que proporcional às necessidades e aos meios reais. (CHEVALIER; GHEERBRANT, 1994, p. $700)$.

\footnotetext{
${ }^{8}$ Filho de Dédalo que lhe ofereceu umas asas para ele fugir da prisão-labirinto de Minos (rei de Creta). Levantou voo sobre o mar onde acabou por morrer afogado por não ter tido em conta o conselho do pai de não voar perto do sol. A cera das asas derreteu-se devido à ação solar, acabando por se precipitar no mar: "Ícaro é o símbolo da desmesura e da temeridade, a dupla perversão do juízo e da coragem" (CHEVALIER \& GHEERBRANT, 1994, p. 372).
} 
Finalmente, importa sublinhar que o voo é um símbolo ascensional (DURAND, 1984, p. 138-178) integrado no regime diurno do imaginário caracterizado pelas estruturas heroicas (DURAND, 1984, p. 67-215).

Do imaginário do voo passamos ao das ilhas sempre rodeadas de mar e impregnadas de ar em rebuliço, mas também onde o silêncio mais se faz ouvir!

\subsection{O imaginário das ilhas}

Sara Maitland, sem dúvida, estava embrenhada numa espécie de "poética do devaneio", tal como a tratou Gaston Bachelard (1984), porque depois da observação das aves dedicou-se às ilhas, tradicionalmente associadas ao silêncio: "As ilhas alimentam um sonho romântico: desde o atol de corais aos penhascos batidos pelas tempestades, representam algo de profundo na psique humana solidão, aventura, silêncio e, talvez de uma forma mais subtil, uma fronteira, uma sensação de personalidade separada e completa. [...] Mas as ilhas são reais” (MAITLAND, 2011, p. 226). Estreitamente ligado à paisagem da ilha encontra-se o farol com o seu faroleiro, quando ele ainda existe, que a autora assemelha ao eremita secular com a sua espécie de vocação eremita silenciosa. De facto, não podemos não pensar no par solidão-silêncio que a figura, por vezes fantasmática, do faroleiro tanto parece evocar (MAITLAND, 2011, p. 228). A ilha que a autora está pensando é a ilha de St. Kilda que, apesar de todo o seu encanto, beleza e silêncio, rodeada de mar encarapelado, não era aquilo que ela necessitava porquanto, como ela o afirma, "o movimento infindável e o som do mar não era o meu silêncio" (MAITLAND, 2011, p. 235). A autora preferia, mais do que o sentido de propriedade, experienciar "a sensação de liberdade, o direito de vaguear de um lado para outro" (MAITLAND, 2011, p. 236).

A ilha está associada aos simbolismos do refúgio, do microcosmos, do mundo reduzido, do espaço circular perfeito, do templo natural que emerge das águas e do Centro primordial e sagrado, uma espécie de "terra santa” (GUHL, 1972, p. 45-50). A acreditar em Juan Cirlot, a ilha "é um símbolo de isolamento, de saudade e de morte" (1997, p. 263). A ilha, para o mesmo autor (1997, p. 263) e 
para Gilbert Durand, representa a "imagem mítica da mulher, da virgem, da mãe” (DURAND, 1984, p. 274; BIERDERMANN, 1996, p. 320) e está ligada ao simbolismo amniótico. Já para Jung a ilha é o refúgio no meio do mar (símbolo do inconsciente coletivo), afirmando-se face a este como a síntese da consciência e da vontade: “A ilha é o refúgio onde a consciência e a vontade se unem para fugirem aos assaltos do inconsciente: contra as vagas do oceano, procura-se o socorro da rocha” (CHEVALIER \& GHEERBRANT, 1994, p. 374; CIRLOT, 1997, p. 262). Por seu lado, Hans Biedermann salienta que "Retirar-se para uma ilha é então efetuar um regressus ad uterum e procurar nas suas origens o princípio primordial que renovará a nossa vida" (1996, p. 320). De acordo com Jean Chevalier e Alain Gheerbrant a ilha é o símbolo por excelência

\begin{abstract}
dum centro espiritual, e mais concretamente do centro espiritual primordial [a bold no texto]. [...] Os Celtas sempre representaram o outro mundo e o além maravilhoso [a bold no texto]. A ilha é, pois, um mundo em pequeno formato, uma imagem do cosmos, completa e perfeita, porque ela representa um valor sagrado concentrado [a bold no texto]. A noção aproxima-se assim da do templo e do santuário [a bold no texto]. A ilha é, simbolicamente, um lugar de eleição, de ciência e de paz [a bold no texto], no meio da ignorância e da agitação do mundo profano. Representa um Centro primordial, sagrado por definição, e a sua cor fundamental é o branco. (CHEVALIER; GHEERBRANT, 1994, p. 374; ELIADE, 1994, p. 471-473).
\end{abstract}

Gilbert Durand (1984, p. 269-307) integra a ilha nos símbolos de intimidade do regime noturno do imaginário (estruturas místicas), cujos simbolismos são os de continente, de proteção, de repouso, de berço ctoniano, de ventre materno, de microcosmos e mesmo de centro e sepulcro.

Em seguida, analisamos o imaginário da floresta onde também o silêncio habita e espreita aquele que nela caminha.

\title{
2.30 imaginário da floresta
}

Do devaneio poético da ilha (sob os signos da terra-água-ar) Sara Maitland passa para outro território tradicional do silêncio - o da floresta. Confessa o seu medo das florestas e acrescenta que não está sozinha, pois outros "sentem medo ou ficam assustados nesses ambientes" (MAITLAND, 2011, p. 236). Fala do 
desconforto de passear ou entrar nas florestas atuais na Grã-Bretanha devido à “atmosfera artificial 'morta' da maior parte das florestas que conhecemos - a enorme monocultura de abetos sitka (Picea sitchensis) que se espalha de forma obscura e deselegante por grande parte das áreas mais selvagens da Grã-Bretanha” (MAITLAND, 2011, p. 236). Paralelamente a este desconforto sobressai um medo mais fundo - o ctónico: "as florestas são aquilo a que Freud chamou heimlich unheimlich - são sinistras. No interior da maior parte dos adultos pós-iluministas e pretensamente racionais existe uma criança que se sente aterrorizada pela floresta selvagem" (MAITLAND, 2011, p. 237, p. 251). O que assusta o adulto de hoje quando confrontado com uma centenária floresta é o silêncio denso que ela exala acompanhada dos seus odores fortes e inebriantes: a floresta aparece como tremenda, como algo que inspira simultaneamente terror e fascínio. Numa palavra, desconhecida e, por conseguinte, misteriosa. Por isso, o contacto com uma floresta secular, suscita em nós um terror ctónico e nos confronta com os nossos próprios medos, sobre a nossa escuridão e sobre a sensação profunda "de que a violência e a beleza, o risco e a alegria, estão indissoluvelmente ligados entre si; e as raízes estão nas florestas” (MAITLAND, 2011, p. 239). Assim, o tema humano ancestral e universal do silêncio casa-se bem com o tema humano ancestral e universal do medo encantatório que a floresta desperta em nós, e dos silêncios por ela exalados: “O silêncio das florestas diz respeito aos segredos, às coisas que estão escondidas. A maior parte dos espaços de silêncio - desertos, montanhas, oceanos, ilhas e charnecas - tem vistas austeras mas amplas. [...] Mas o silêncio das florestas esconde coisas, não as abre, fecha-as” (MAITLAND, 2011, p. 243). E nesse sentido, a floresta aparenta-se com o segredo porque ambos apelam à proteção do dito e ambas pressupõem uma iniciação adequada: assim como há o silêncio dos segredos, em que o revelado secretamente não pode ser desvelado ao noviço (MAITLAND, 2011, p. 251-252), ou seja, também a floresta encerra os seus silêncios somente acessíveis aos iniciados (MAITLAND, 2011, p. 245-247).

A floresta simboliza as poderosas manifestações da vida e do próprio inconsciente e, como tal, é geradora de sentimentos ambivalentes: angústiaserenidade, e de opressão-simpatia. É menos aberta que a montanha, menos árida 
que a ilha, mais húmida e lunar que o deserto, ela é, contudo, silenciosa, sombria, estanha, inquietante, desordenada ameaçadora, secreta, enigmática, perigosa e fonte do desejo e do mal (CHEVALIER; GHEERBRANT, 1994, p. 330-331). A floresta representa o mundo exterior e é símbolo de um universo que se opõe ao microcosmo desflorestado:

ela pode tornar-se o lugar de isolamento para o homem preocupado com a espiritualidade, em que ele se encontra em segurança e ao abrigo da agitação do mundo. Os eremitas não temem os seus perigos e nela encontram proteção contra os poderes maléficos. A floresta torna-se assim o equivalente do deserto em que o meditativo se retira afastado das comédias da vida, num retorno às forças primitivas que podem revelar mais a essência e a unidade da sua alma, e onde se confronta sem apelo face a si próprio e ao divino. (BIEDERMANN, 1996, p. 273).

Para Gilbert Durand a floresta, cujo horizonte se fecha em si próprio, representa um centro de intimidade à semelhança da casa, da gruta ou da catedral: "O espaço fechado da floresta é constitutivo do lugar sagrado. Todo o lugar sagrado começa pelo 'bosque sagrado’. O lugar sagrado é uma cosmização, mais ampla que o microcosmos da casa, do arquétipo da intimidade feminina” (DURAND, 1984, p. 281). Neste sentido, Gilbert Durand (1984, p. 269-307) integra a floresta nos símbolos de intimidade do regime noturno do imaginário (estruturas místicas) cujos simbolismos são os de profundidade, de microcosmos e de repouso.

Depois da floresta, temos as imagens do deserto que, a seu modo, é também uma espécie de floresta, mas sem árvores despida da sua roupagem floral e ausente de sombras.

\subsection{O imaginário do deserto}

Sara Maitland, no capítulo dedicado aos "Eremitas do Deserto" (MAITLAND, 2011, p. 257-300), sublinha que uma das caraterísticas marcantes do deserto é que nele o silêncio se torna ou se faz denso. A autora fez um retiro espiritual no deserto do Sinai, mais propriamente em White Wadi, segundo a tradição dos Padres do Deserto, conhecidos por serem os primeiros eremitas cristãos (The Desert Fathers, 1998). O objetivo de passar algum tempo neste lugar 
era conhecer uma espécie de silêncio específico, ou seja, um silêncio do retiro interior. Um tipo de silêncio que lhe permitisse imitar o modo como os eremitas cristãos se aproximaram do Divino mediante a exploração do silêncio radical. Salienta a autora que, durante uma semana, sentada numa escarpa, dedicou-se a orar e a pensar o e no silêncio: "Para além disso, não havia nada; um enorme e cálido nada. Foi o silêncio mais profundo que jamais conheci. Não havia nada para ouvir" (MAITLAND, 2011, p. 267). Durante esse tempo, Sara Maitland começou ouvindo o "som do silêncio", uma espécie de canção misteriosa, que, paradoxalmente, “é a ausência seja do que for para escutar” (MAITLAND, 2011, p. 267). Neste contexto, cita a passagem de Grains of Sand de Martin Buckley (MAITLAND, 2011, p. 268-269):

Sem vácuo, o verdadeiro silêncio implica a ausência de fricção do ar sobre um objeto - o vazio e a quietude que se encontram apenas no deserto. Pairando sobre os binários de pó e céu, castanho-acinzentado e azul, sombra e luz do Sol, o silêncio acaba por se tornar ele próprio um som: um fluxo sibilante de sangue aos nossos ouvidos. (BUCKLEY, 2011, p. 268).

A passagem agora citada ilustra bem o sentimento agora experienciado pela nossa autora. A este sentimento juntou-se igualmente o da lassidão - ad tedium que era uma resposta típica à solidão e ao calor do deserto. Durante a sua estadia Sara Maitland levava consigo para as rochas a tradução de Helen Waddell intitulada The Desert Fathers ${ }^{9}$ procurando ler os relatos, nomeadamente a vida de António por ser o fundador da tradição monástica e o primeiro dos Padres do Deserto. Mergulhada "no silêncio do próprio deserto", dedicava-se a "pensar nas experiências deles e como essas experiências poderiam estar relacionadas com a minha” (MAITLAND, 2011, p. 277). A autora relata que na última noite passada em White Wadi manteve-se acordada até ao amanhecer: "Ao longo de toda a noite prestei atenção - atenção ao nada. O silêncio era extremamente puro" (MAITLAND, 2011, p. 297). No interior da noite do deserto em que o silêncio era denso dando a sensação de que tudo estava enterrado num sepulcro: "Era provavelmente o silêncio mais profundo em que jamais estivera envolvida. Havia sido esta intensidade do silêncio que ali tinha ido ouvir" (MAITLAND, 2011, p.

\footnotetext{
${ }^{9}$ Trata-se de "uma coletânea com as afirmações dos eremitas sobre a vida eremítica - recolhidas por diversos contemporâneos - a qual se tornaria imensamente influente na Igreja ao longo de muitos séculos" (MAITLAND, 2011, p. 277, p. 285-289).
} 
298). Um silêncio tantas vezes experienciado e vivido pelos eremitas do deserto e que Sara Maitland agora poderia igualmente usufruir e vivenciar. E deste modo, diz-nos que nessa mesma noite começou a ouvir o "som do silêncio" (já por nós evocado) de John Cage sob um novo olhar, ao ponto de lhe parecer "ouvir o cantar das esferas" (MAITLAND, 2011, p. 299), indo mesmo mais longe: "O som do silêncio, naquela noite do deserto, era a canção da jouissance, da bênção" (MAITLAND, 2011, p. 299). Por isso mesmo é que o silêncio no deserto é especial: ajuda aquele que o pratica a "participar na liberdade indefinida e ilimitável do divino" (MAITLAND, 2011, p. 299), ainda que a autora se questione sobre esse grande silêncio: "Comecei a pensar que talvez o silêncio seja Deus. Talvez Deus seja o silêncio - o anel brilhante e que está sempre a rodar com a 'luz pura e infindável. [...] Deus é silêncio, um silêncio que é positivo, vivo, presente e, pela sua própria 'natureza', inquebrável' (MAITLAND, 2011, p. 300).

Mas, aquilo que nos interessa aqui destacar é a sua aprendizagem intelectual e emocional sobre o silêncio no deserto: "Tinha amado e sentira-me profundamente atraída pelo silêncio dos eremitas do deserto - que optaram, com tanto esforço, por esvaziar as suas mentes e corações. Mas também tinha consciência de que este conceito é profundamente estranho para a nossa cultura” (MAITLAND, 2011, p. 309). Esta aprendizagem fê-la compreender que o silêncio, por ela vivido no deserto, é mais do que um contexto para a oração, ou mesmo uma forma de ter uma perceção mais ampla do próprio tempo: o silêncio é em si próprio "uma forma de liberdade; gera mais liberdade, permite o livre-arbítrio, confere clareza interior e força. Concede a liberdade relativamente à nossa própria personalidade e a liberdade de sermos nós próprios" (MAITLAND, 2011, p. 300).

O símbolo do deserto ${ }^{10}$, de acordo com a sua natureza, é ambivalente e deve ser encarada a partir da imagem da solidão: "sem Deus é a esterilidade, com Deus é a fecundidade, mas devida só a Deus. O deserto revela a supremacia da graça: na ordem espiritual nada existe sem ela; tudo existe por ela e só por ela”

\footnotetext{
${ }^{10}$ No Dicionário dos Símbolos de Jean Chevalier e de Alain Gheerbrant lê-se: “O deserto comporta dois sentidos simbólicos essenciais: é a indiferença inicial, ou a extensão superficial, estéril, sob a qual deve ser procurada a Realidade” (1994, p. 259-260).
} 
(CHEVALIER; GHEERBRANT, 1994, p. 260). O deserto é símbolo do vazio, da terra e sol ardentes, onde a sequidão e a solidão convivem lado a lado: "é o clima por excelência da espiritualidade pura e ascética, da consumação do corpo para a salvação da alma” (CIRLOT, 2000, p. 170-171). Representa um lugar onde cada um faz a sua aprendizagem espiritual e faz o seu caminho para alcançar a sua maturidade espiritual, ou seja, é uma etapa necessária no crescimento espiritual do homo viator. Simboliza a renúncia à vida social e encarna a solidão nos seus diferentes estados. Lugar ideal para a revelação e a renovação espiritual. Quando Gilbert Durand (1984, p. 269-307) escreve sobre os "símbolos de intimidade”, faz notar que uma das qualidades negativas do universo hostil ao repouso e à profundidade (ideias próprias dos símbolos de intimidade) é a da seca, que é uma das caraterísticas fortes do deserto, além da claridade (dia - ciclo solar) por oposição às trevas (noite - ciclo lunar) (DURAND, 1984, p. 306). Por isso, o deserto é um símbolo solar e mesmo espetacular, enquadrado no regime diurno do imaginário (estruturas heroicas), marcadamente luminoso e dourado (DURAND, 1984, p. 162-178). Pressupõe uma verticalização ascensional e uma forte presença de símbolos ligados à luz e mesmo ao conhecimento implicando já a transcendência e a purificação: "É aquilo que já nos deixava entrever a ascese catártica da ascensão alada e a propensão do pássaro a transmutar-se em anjo" (DURAND, 1984, p. 178). É neste sentido que a experiencia existencial de Sara Maitland passada no deserto (MAITLAND, 2011, p. 256-300) nos conduz, particularmente quando ela escreve: “É, em si próprio [o deserto], uma forma de liberdade; gera mais liberdade, permite o livre-arbítrio, confere clareza interior e força. Concede a liberdade relativamente à nossa própria personalidade e a liberdade de sermos nós próprios" (MAITLAND, 2011, p. 300).

Passemos agora, ao imaginário da montanha, que nos abre a um outro tipo de solidão e de novos matizes de silêncio. 


\subsection{O imaginário da Montanha}

Sara Maitland deixou o deserto, trocando-o pela solidão da montanha, experiência que descreve num capítulo chamado: "A Benção da Solidão" (MAITLAND, 2011, p. 300-346). Os Alpes, como arquétipo do "belo bruto, simbolizavam para os românticos a vertigem e a sensação de horror/terror e a apoteose do sublime (MAITLAND, 2011, p. 301-303) ${ }^{11}$ e onde, aliás, eles buscavam também retirar-se mesmo religiosamente falando. Neste contexto, citou Shelley, a propósito do "Mont Blanc" (o seu poema de 1817): "E que serias tu, a terra, as estrelas e o mar/, Se para os produtos da mente humana/ O silêncio e a solidão fossem vazio" (MAITLAND, 2011, p. 302)? Ela pretendia indagar se o silêncio romântico era profundamente diferente do silêncio do deserto, mesmo que de alguma forma já tivesse essa quase certeza:

E, portanto, os românticos tentavam descobrir a solidão e o silêncio para 'se encontrarem', da mesma maneira que os eremitas do deserto tentavam descobrir o silêncio e a solidão para 'se perderem'. Não é simples coincidência que enquanto os eremitas em geral prefeririam a palavra 'silêncio', os românticos tinham a tendência para utilizar o termo 'solidão'; certamente que não queriam ser silenciados, pretendem usar o silêncio como forma de descobrirem as suas próprias vozes individuais. (MAITLAND, 2011, p. 317).

A "bênção da solidão" (Wordsworth) romântica era aquilo que a autora queria explorar e fê-lo na zona montanhosa de Galloway, levando consigo o Prelúdio (MAITLAND, 2011, p. 320-321, p. 318-319) de Wordsworth (1805). Lá encontrou, à semelhança dos românticos, o lado duro, selvagem, silencioso e belo das paisagens montanhosas durante dez dias de caminhadas ${ }^{12}$. Sobre isso escreveu: "Paisagens como estas fazem-nos olhar para fora de nós e não para dentro, como acontece no deserto" (MAITLAND, 2011, p. 308). Neste sentido, o "retiro" dos românticos nas paisagens inóspitas era muito apreciado porque os ajudava a explorarem a sua personalidade interior, desenvolverem a sua independência e

\footnotetext{
${ }^{11}$ Sobre as caraterísticas do movimento Romântico apontadas pela autora, leia-se O Livro do Silêncio, p. 316-317. Ver também as seguintes obras clássicas sobre o tema: Isaiah Berlin. As Raízes do Romantismo. Trad. de Isa Mara Lando, São Paulo: Três Estrelas, 2015 e Georges Gusdorf. Le Romantisme. Vol. 1. Le savoir romantique; Vol. 2. L'homme et la nature. Paris: Payot \& Rivages, 1993.

12 É de notar que a autora diz claramente: "A paisagem parece ser particularmente importante para os solitários" (MAITLAND, 2011, p. 362). Para um desenvolvimento circunstancial deste tema, ver Maitland (2011, p. 362).
} 
autenticidade, assim como esse mesmo "retiro" lhes permitia manterem-se afastados da vida "civilizada".

Caminhando até ao alto da cumeeira designada Nieve of the Splite, ainda que exausta, tentava "contrastar esta experiência com os momentos em que estava sentada no recanto abrigado das rochas no deserto e procurava esvaziar a minha mente e o meu coração de tudo, e em que tentava ainda pensar na autenticidade e em "dar voz" ao silêncio que me rodeava. Pareceu-me que aprendera algumas coisas (MAITLAND, 2011, p. 309). Aprendera nomeadamente, com Edward Gibbon (1757-1794), que havia duas espécies diferentes de solidão: a solidão do "génio pósiluminismo" e a solidão "selvagem do ascetismo". Aquilo que Sara Maitland aprendeu e herdou das leituras e reflexões sobre o Movimento Romântico foi o conceito de personalidade "interior" verdadeira ou autêntica: "Introspeção e fascínio pela personalidade; uma espécie de consciência aumentada dos estados de espírito e dos pensamentos pessoais” (MAITLAND, 2011, p. 316, p. 330-331). Um tipo de personalidade que carecia de silêncio e de solidão para se afirmar "acima de todas e quaisquer convenções ou obrigações sociais” (MAITLAND, 2011, p. 331) o que se cruzava necessariamente com o tema do indivíduo (MAITLAND, 2011, p. 341-342). Os autores românticos parecem, na verdade, precisar de desposar a solidão e o silêncio, no interior da natureza selvagem, para que a criatividade brote da sua personalidade "interior”. Esta "é mais 'verdadeira' e mais 'real' do que a persona (máscara) socialmente idealizada que colocamos nas circunstâncias sociais, e que a arte mais grandiosa é aquela que resulta da exploração e exposição dessa personalidade escondida” (MAITLAND, 2011, p. 323).

Daí a autora salientar que é necessário partir para as grandes paisagens românticas, como as pintadas por Caspar David Friedrich (1774-1840), para apreciar o sublime, descobrir a identidade autêntica de cada indivíduo, dar ênfase à sua imaginação, espontaneidade e liberdade emocional. Tudo isto concorreria certamente para idealizar o artista como espírito criativo e livre: "cuja expressão da emoção pessoal autêntica era mais importante do que a forma” (MAITLAND, 2011, 
p. 316). Seria, portanto, aquilo que Sara Maitland denomina de "personalidade narrativa":

Optar por estar sozinho, solitário, particularmente num local que é 'sublime', é uma forma de estabelecer contacto com essa narrativa, que não é mediada pela interpretação de outras pessoas. Acabei por sentir que efetivamente se trata de descer (ou entrar/subir/atravessar/ passar) internamente para um outro nível - e há bocados de recordações que estão por ali. Em $1^{\circ}$ lugar, o silêncio coloca-nos nesse 'outro' local e, em segundo lugar, concede-nos uma oportunidade, sem interrupções ou comentários, de recuperarmos e moldarmos essas recordações. (MAITLAND, 2011, p. 323).

Todo este sentimento existencial vivido pela autora em Galloway reforça a ideia de que o silêncio inspira a atividade criativa, em particular de carácter literário. Neste sentido, questiona-se se a personalidade “interior”, através da natureza-solidão-silêncio, seria mesmo mais real do que a personalidade socialmente idealizada. No entanto, admite que esta ideia encontra-se profundamente inculcada no imaginário cultural ocidental, ou seja, a ideia de que a solidão fomenta a criatividade e que, por conseguinte, nenhum artista a poderá dispensar. A este respeito, cita novamente Wordsworth que, na solidão, procurou também ele próprio “descobrir e fortificar a sua verdadeira personalidade” (MAITLAND, 2011, p. 329). O tempo passado em Galloway, com as suas caminhadas longas, maravilhosas e extenuantes, permitiu-lhe aprender o modo como a sua percepção da natureza e da experiência religiosa, e até mesmo da sua própria personalidade, assentava sobre uma visão romântica da vida e do mundo, ao contrário daquilo que ela pensava quando da sua estadia no Sinai: "Depois do Sinai, tinha começado a sentir que toda a minha inclinação e esforços iam no sentido do silêncio eremítico - o duro confronto com a força e a tenacidade do ego - e não com a noção romântica de que o ego necessita de suporte” (MAITLAND, 2011, p. 335). Também a sua estadia no deserto lhe permitiu aprender que há duas correntes distintas no envolvimento na solidão e no silêncio no meio da natureza: a moralista, que defende a Natureza como formadora autêntica, (Rousseau, Wordsworh, Thoreau, etc.) e a amoralista, que é a da selva, que permite ao espírito humano abrir-se à loucura (criativa!) (Shelley, Emily Bontë, de Poe e de Kerouac), 
(MAITLAND, 2011, p. 337). Aprendeu igualmente, ao longo das caminhadas que fez em Galloway, que existe algo de profundamente diferente entre este entendimento romântico (silêncio romântico) e a perspetiva religiosa mais antiga sobre o silêncio (silêncio religioso ou eremítico) (MAITLAND, 2011, p. 237-238)13.

No tocante à simbólica da montanha, esta é vasta porque representa o encontro do céu e da terra, domina o mundo dos homens e é símbolo da elevação em si-mesma, simboliza, quer a independência, a grandeza e a pretensão do homem face à omnipotência do Divino, quer a proximidade de Deus e da sua omnipotência e, como tal, o cume da montanha, geralmente envolto de nuvens, representa um desejo ideal de ser alcançado, bem como possui uma aura misteriosa e divina. O simbolismo do centro do mundo, do umbigo do mundo e da imensa altitude também é significativo:

Na medida em que ela é alta [a montanha], vertical, elevada, próxima do céu, participa do simbolismo da transcendência: na medida em que é o centro de hierofanias atmosféricas e de numerosas teofanias, participa do simbolismo da manifestação. [...] Vista do alto, aparece como a ponta duma vertical, é o centro do mundo; vista de baixo, do horizonte, aparece como a linha duma vertical, o eixo do mundo, mas também a escada, a inclinação a escalar. (CHEVALIER; GHEERBRANT, 1994, p. 456).

As peregrinações em direção às montanhas sagradas simbolizavam pela sua parte o desprendimento progressivo da esfera quotidiana e a elevação espiritual. (BIEDERMANN, 1996, p. 419).

Mas o simbolismo mais profundo da montanha é aquele que outorga um caráter sagrado, refundindo a ideia de massa, como expressão do ser, e a verticalidade. Como no caso da cruz ou da árvore cósmica, a localização dessa montanha é símbolo do 'centro' do mundo. [...] Em geral, a montanha, a colina, o cume estão associados à ideia de meditação [o caso dos românticos], de elevação espiritual, de comunhão dos santos. [...] No seu aspeto total, a montanha fulgura branquíssima, o que a identifica como montanha polar e imagem sintética da totalidade (pirâmide) tendendo à unidade (cume) segundo os conceitos de Nicolau de Cusa. (CIRLOT, 2000, p. 315-316-317).

\footnotetext{
${ }^{13}$ Tratamos desta questão na primeira parte do nosso artigo.
} 
Do ponto de vista psicológico, Paul Diel diz que a montanha representa a função psíquica supraconsciente que tem como tarefa conduzir o homem até ao cume do seu desenvolvimento (1970). As ideias de elevação espiritual, de ascensão, de verticalidade encontram-se associadas ao simbolismo da montanha. Ela é igualmente considerada um símbolo fálico masculino. A montanha envia para o simbolismo de ascensão que Gilbert Durand diz que é o contrário da queda. A ascensão, como oposta de abismo, labirinto, sol negro, tumba, esgoto, boca, é conotada com o heroísmo: "A ascensão constitui por conseguinte a 'viagem em simesmo', a 'viagem imaginária' mais real de todas que sonha a nostalgia inata da verticalidade pura, do desejo de evasão ao lugar híper, ou supra, celeste" (DURAND, 1984, p. 141). Neste sentido, Gilbert Durand (1984, p. 138-144) inclui a montanha nos símbolos ascensionais do regime diurno do imaginário (estruturas heroicas) cujas ideias são as de verticalidade e de ascensão.

Do imaginário da paisagem montanhosa dos românticos passamos ao "mergulho" nas profundezas do silêncio.

\subsection{O imaginário do mergulho nas profundezas do silêncio}

A imagem do mergulho, que implica sempre uma descida em profundidade, é uma metáfora feliz para ajudar-nos a melhor entender a natureza do silêncio:

É uma boa metáfora sob inúmeros aspectos - existe profundidade no silêncio. $O$ silêncio absorve-me e quanto mais entro nele, mais me sinto pressionada por ele. No silêncio, tal como nas águas profundas, ficamos libertos da gravidade. [...] E, tal como nas águas profundas, podemos afundar-nos no silêncio. O perigo está sempre presente. (MAITLAND, 2011, p. 379-380).

Sara Maitland, não obstante considerar esta uma boa imagem, diz no seu último capítulo: A Chegada a casa (MAITLAND, 2011, p. 347-386), que é agora, adepta de uma outra imagem completamente distinta, semelhante à descrita por Costeau: de sair das profundezas do mar deixando lá no fundo todo o equipamento de mergulho. É, portanto, agora este tipo de ritual de subida, envolta de bolhas 
libertadoras, que atrai Maitland e lhe serve de motivo para falar da sua relação com o silêncio:

O silêncio paira numa atmosfera nova e mais leve, sem peso e livre, e quando produz uma corrente de bolhas, bolhas de alegria, elas flutuam à nossa volta e sobem em direção a uma superfície brilhante, que ainda não conseguimos ver claramente. Começo a florescer neste novo ambiente. (MAITLAND, 2011, p. 380).

O mergulho nas profundezas é uma metáfora aquática, fortemente conotada pelos verbos descer e penetrar, diferente das metáforas ditas de superfície dadas pelos verbos, nadar, surfar e navegar. Mergulhar é aprofundar a nossa perspetiva, o nosso ângulo de visão, mudando nossa posição relativa à superfície e descendo a níveis que não estavam aparentes enquanto surfávamos ou navegávamos. É penetrar nos interstícios do silêncio, para poder descer mais fundo na tentativa de escutar o silêncio interior, indo além da superfície, ou seja, do silêncio exterior. Mergulhar refere-se também a uma busca, a uma exploração mais sistemática, ligada tanto à observação do caminho quanto do próprio substrato no qual estamos imersos. Se atendermos à “classificação isotópica das imagens” de Gilbert Durand (1984, p. 506-507) podemos associar esta metáfora aos símbolos catamórficos (DURAND, 1984, p. 122-134) do regime diurno do imaginário (estruturas heroicas). No quadro destes símbolos temos a considerar a imagem dinâmica da queda. O mergulho assemelha-se a uma queda que não é mais do que uma descida dinâmica do alto para baixo, ou seja, para as profundezas. Assim, se a ascensão é um apelo à exterioridade (ao alto), o mergulho é um apelo à interioridade (ao baixo). O mergulho é uma queda, ou uma descida, fulgurante na/à profundidade obscura, misteriosa e incógnita do silêncio:

A recusa da ascensão adquire a aparência do peso ou da gravidade negra [...] A queda estando aliás conectada, como o sublinha Bachelard, à rapidez do movimento, à aceleração como às trevas, admite-se que ela seja a experiência dolorosa fundamental e constitua para a consciência a componente dinâmica de toda a representação do movimento e da temporalidade. A queda resume e condensa os aspetos temíveis do tempo, "ela faz-nos conhecer o tempo mortal". (DURAND, 1984, p. 123-124).

O mergulho na profundidade do silêncio é libertador porque liberta da gravidade. O silêncio das profundezas, à semelhança das águas profundas, aplaca a 
vertigem do ruído da tagarelice da palavra e mesmo da sua cacofonia abrindo o sujeito ao reino vasto do silêncio interior. Da metáfora do mergulho nas profundezas do silêncio chega à metáfora do silêncio do buraco negro.

\subsection{Imaginário do silêncio como um buraco negro}

A metáfora do silêncio do buraco negro interpela-nos e nos faz ir mais longe no caminho da compreensão do silêncio:

Por vezes, penso que o silêncio é como um buraco negro: num buraco negro a força de gravidade é tão forte que nada nem mesmo a luz, pode escapar para o exterior. Tudo aquilo que se aproximar do alcance dessa força é irreversivelmente atraído, sugado, comprimido, esmagado compactado, até entrar em colapso sob a concentração da sua massa. (MAITLAND, 2011, p. 385).

O silêncio, como um buraco negro, bem pode ser a morte, o nada, bem como pode ser o nascimento, dependendo da ótica do observador. Aquilo que para lá dele possa existir bem pode ser "um universo alternativo localizado para além das leis da física e da psique, para um novo universo, para Deus" (MAITLAND, 2011, p. 386). Mesmo sabendo e sentindo que o silêncio é profundamente misterioso, a autora quer descobrir tal universo e para isso precisa encarar esse silêncio, porque é a única forma de descobrir o que existe do outro lado. O que existe para além do buraco negro do silêncio está esperando ser descoberto, indagado, nem que para isso seja necessário mergulhar nesse mesmo buraco sem-fundo, uma espécie de nada que é Tudo, parafraseando aqui o verso da Mensagem de Fernando Pessoa quando ele diz que "O mytho é o nada que é tudo".

O imaginário do silêncio como buraco negro aparentemente está associado aos símbolos da casa, da caverna, do labirinto e da gruta. O denominador comum entre esses símbolos é que eles são uma espécie de contentores, ou seja, são símbolos que contêm, abrigam ou escondem algo ou alguma coisa. Neste sentido, funcionam como símbolos recipientes, e por isso Gilbert Durand os filiou ao regime noturno do imaginário, mais especificamente integra-os nos chamados símbolos de intimidade (DURAND, 1984, p. 269-307), marcados pelas estruturas místicas do 
imaginário (DURAND, 1984, p. 307-320). O regime noturno do imaginário, com os seus símbolos noturnos, usa os símbolos de inversão (DURAND, 1984, p. 225-268) e da intimidade (DURAND, 1984, p. 269-307) como antídoto contras as faces do tempo:

O antídoto do tempo não será mais procurado ao nível do sobre-humano, da transcendência e da pureza das essências, mas na tranquilizante e quente intimidade da substância ou das constantes rítmicas que acentuam fenómenos e acidentes. Ao regime heroico da antítese vai suceder o regime integral do eufemismo. (DURAND, 1984, p. 220).

Deste modo, a metáfora do "silêncio como um buraco negro", desenhada por Sara Maitland no final do seu livro, parece bem dar conta da natureza, quer dos símbolos de inversão, quer dos símbolos de intimidade, porque na qualidade de metáfora axiomática, na expressão de Gaston Bachelard (2004, p. 17), acentua a tranquilidade da descida e da intimidade por contraposição à dinâmica da ascensão e, por conseguinte, à transcendência: “a força da gravidade é tão forte que nada, nem mesmo a luz, pode escapar para o exterior. [...] O próprio tempo anda mais devagar” (MAITLAND, 2011, p. 385). A este respeito, o regime do eufemismo, no sentido que Gilbert Durand lhe confere ${ }^{14}$, está presente quando Maitland escreve: "Isto é a morte, como é evidente, mas também pode ser o nascimento, dependendo da posição do observador" (MAITLAND, 2011, p. 386).

Não deixa também de ser interessante que a autora tenha escolhido uma metáfora deste género, com o imaginário que lhe está subjacente, mesmo no final da sua autobiografia do silêncio porque a sua escolha parece indicar, senão mesmo resumir, o modo como ela encara o próprio silêncio, isto é, metaforicamente: “o silêncio é como um buraco negro" (MAITLAND, 2011, p. 385).

Tendo em conta o modo como a autora se refere ao silêncio, pensamos simultaneamente em dois tipos de símbolos que melhor o descrevem: os de

\footnotetext{
${ }^{14}$ Sobre o tema do eufemismo, Gilbert Durand escreve: “A côté du processus métaphysique qui, par les symboles antithétiques, par la fuite ou par le glaive, combat les monstres hyperboliques engendrés par l'angoisse temporelle, à côté d'une attitude diaïrétique, d'une ascèse transcendante, la duplicité permettant l'euphémisation de la mort elle-même ouvre à l'imaginaire et aux conduites qu'il motive une toute autre voie. [...] Le sens suprême de la fonction fantastique dressée contre la destinée mortelle, est donc l'euphémisme. C'està-dire qu'il y a en l'homme un pouvoir d'amélioration du monde » (DURAND, 1984, p. 220, p. 470).
} 
inversão (cujos exemplos são: buraco sem fundo, garganta funda e abismo sem fim) e de intimidade (caverna-gruta). O primeiro tipo de símbolos exprime as imagens angustiantes que lhe estão associadas, assim como toda a temática da descida, da escuridão, da interioridade e, obviamente, da profundidade obscura; já o segundo tipo de símbolos exprime as ideias de intimidade e de repouso, além de estar intimamente ligada ao elemento terra.

Sara Maitland ao escrever "que o silêncio é como um buraco negro" (MAITLAND, 2011, p. 385) está, sem o saber, a remetê-lo para o imaginário noturno - acompanhado dos seus símbolos de "inversão" e de "intimidade”, com as suas estruturas místicas (DURAND, 1984, p. 307-320)15 - que dá conta da natureza profunda da metáfora do "silêncio como buraco negro".

A nossa última parte pretende realçar os nós de entrelaçamento entre a trilogia do silêncio-imaginário-criatividade. Um entrelaçamento já de per se complexo que procura enfatizar como o imaginário do silêncio se faz ou se torna criativo: "O silêncio por opção pode ser criativo e gerar autoconhecimento, integração e profunda alegria” (MAITLAND, 2011, p. 255). A imaginação, irmã siamesa da criatividade, alimenta-se particularmente do recolhimento, da meditação e da contemplação, mesmo de uma certa ascese que os vários tipos de silêncio lhe proporcionam. As obras da imaginação dão-se a conhecer pelo imaginário que as acolhem no seu seio para melhor as mostrar, seja através de obras de arte, de filmes e óperas, seja através da literatura e da poesia e das ciências.

\section{Silêncio, Imaginário e Criatividade}

O silêncio pode e deve irrigar com a sua seiva criativa e produtiva a Palavra que, graças a ele, se torna, tantas vezes, criativa e por que não iniciática! Neste sentido, poderemos compreender quando Maitland salienta que a tarefa da palavra

\footnotetext{
${ }^{15} \mathrm{O}$ schème "verbal" principal que carateriza as estruturas místicas é o de "confundir" que, por sua vez, subsume outros três schèmes: os de "descer", de "possuir" e de "penetrar". Não esquecendo também que as qualidades dessas mesmas estruturas são dadas pelos arquétipos "epitéticos" que são os seguintes: "profundo", "calma”, “quente", "íntimo" e "escondido" (DURAND, 1984, p. 506-507).
} 
é desejar quebrar os tipos de silêncio que a envolvem. Esses silêncios, aos quais a autora se refere, atrás designados como: religioso (do deserto ou eremítico) e romântico, são agora denominados: o primeiro espiritual e o segundo criativo. A questão fulcral que se colocava a Sara Maitland é que ela pretendia fruir ambos os silêncios A autora procurava integrar os dois tipos de silêncio, ou seja, ela procurava concretizar ambos os silêncios, vivê-los como se fossem um só: "procurando o seu próprio vazio silencioso [silêncio espiritual] interior em comunhão com o seu Deus e criando literatura [silêncio criativo]" (MAITLAND, 2011, p. 347). Embora privilegie a oração quenótica, o silêncio espiritual prejudica a afirmação da personalidade e da própria vontade, enquanto o silêncio criativo, ao privilegiar a vontade própria e a afirmação de uma personalidade forte, estimula as narrativas fortes. Porém, nada melhor do que dar a palavra à autora:

Demasiada atenção à oração quenótica, de autoesvaziamento, à destruição, derruba as delimitações da personalidade, e estas, enfraquecidas, evitam a criação de uma narrativa forte, [isto é, não estimula a fonte da criatividade]. E vice-versa. Mas eu continuava a querer os dois géneros de silêncio. (MAITLAND, 2011, p. 347) ${ }^{16}$.

Sara Maitland ansiava viver e escrever em silêncio e estava decidida a fazêlo; e, embora admitisse que não sabia bem como o deveria fazer, mantinha sua firme intenção de descobrir: "Ambicionava ser, em simultâneo, uma pessoa que habitava no silêncio e uma escritora” (MAITLAND, 2011, p. 349). Pretendia casar a palavra com o silêncio e isso só poderia acontecer porque ambos não eram incompatíveis: O silêncio, ao contrário daquilo que é afirmado por certo tipo de sensibilidade, não é uma ausência, um vazio, enfim uma privação da liberdade, mas antes - e falamos do silêncio interior seja ele religioso, romântico ou mesmo o silêncio psicanalítico positivo, - uma presença viva, semântica e espiritualmente vivificadora da palavra e para a Palavra. O silêncio é uma via privilegiada para aceder-se à linguagem:

\footnotetext{
${ }^{16}$ Ambos os silêncios tinham sido, segundo a autora, vividos por personalidades, tais como Hildegarda de Bingen, João da Cruz, Juliana de Norwich, Annie Dillard e Thomas Merton (MAITLAND, 2011, p. 347-348). 0 género literário daqueles ou daquelas que praticam o esvaziamento da sua personalidade é o da autobiografia. Já aqueles que vivem plenamente a sua personalidade - os românticos preferem a forma poética: "Talvez porque a ficção implica a criação de novos mundos e essa situação exija uma maior afirmação do ego do que o registo daquilo que surge, como uma oferenda, na nossa própria vida silenciosa" (MAITLAND, 2011, p. 349).
} 
O silêncio não parece que é uma perda ou uma falta da linguagem, nem sequer aparente ser oposto da linguagem. Descobri que é uma palavra completa em si mesma e por si só, ao lado de, entrelaçado na linguagem e na cultura, mas independentemente dela. É proveniente de um espaço completamente diferente. (MAITLAND, 2011, p. 375).

O silêncio como beleza terrífica, que é mistério fascinante e tremendo, carece também de ser desvendado pelo poder da palavra e do seu semantismo. O silêncio dá que pensar e doa-se privilegiadamente através da metáfora e do símbolo: estes são os seus mediadores privilegiados por serem eles os porta-vozes das imagens profundas que animam os vários tipos de silêncio como, aliás, vimos anteriormente. O silêncio exprime-se na sua amplitude e profundidade na e pela imagem, seja esta ligada ao voo, à montanha, à ilha, à floresta, ao deserto, entre outros. A voz original do silêncio é a imagem e não a palavra porque quando esta é proclamada o silêncio torna-se de imediato raro e fugidio. $\mathrm{O}$ espaço do silêncio tende a ser mais o da imaginação (mythos) do que o espaço da razão (logos) e é, portanto, neste sentido que podemos afirmar que o silêncio pode ser criativo. Falar de silêncio criativo é já outra maneira de dizer imaginativo: "E há algumas [histórias] que entendem que o próprio silêncio é um agente criativo, um poder ativo, um ingrediente vital" (MAITLAND, 2011, p. 177).

O silêncio como agente criativo diz-se no plural pela simples razão que nem todos os silêncios se equivalem: o tipo de silêncio eremítico não é o mesmo que o dos artistas criativos. Serão os dois tipos de silêncio conciliáveis como a autora gostaria que o fossem? Será que ambos são passíveis de coexistiram na mesma pessoa: "ser uma pessoa que reza, que tenta encontrar a união com o divino, e ser uma pessoa que escreve, e, em particular, narrativas em prosa?”. Esta é uma das questões fulcrais do nosso estudo na base das preocupações da autora. Por outras palavras, que tipo de silêncio, com o imaginário que lhe está adjacente, poderá dar conta duma criatividade que seja produto de ambos os silêncios, o eremítico religioso e o romântico, vividos como se fossem um só?

A resposta que antevemos surge-nos do lado de um tipo de silêncio oximoro (uma coincidentia oppositorum), cuja imagem bem poderia ser a de "um enorme e 
cálido nada”, enfim, de um silêncio em que simultaneamente nada ouvíssemos (o nada longínquo próprio da enormidade do silêncio conhecido dos místicos, dos eremitas do deserto, mesmo dos budistas) (MAITLAND, 2011, p. 337) e que tudo ouvíssemos. Ou seja, que fossemos capazes de ouvir o som do silêncio sob a forma do "cantar das esferas ou de canção da jouissance, da benção" (MAITLAND, 2011, p. 299). Ambos os silêncios - o silêncio religioso eremítico simbolizado pelo deserto e o silêncio romântico simbolizado pela montanha - podem ser vividos pela mesma pessoa de modo criativo desde que não sejam encarados como opostos, como à primeira vista parecem, mas de natureza diferente em que esta não é somente dada pelas suas diferenças conceptuais, mas pelo tipo diferente de imaginários que lhes está subjacente: principalmente pelos imaginários do deserto e da montanha, sem contudo descurar os demais imaginários tratados. Esta questão, que faz a diferença, não foi, contudo, trabalhada por Sara Maitland, isto é, as dimensões imaginárias do silêncio, e da sua importância, ter-lhe-ão passado ao lado.

Pelo exposto, podemos afirmar que os vários tipos de silêncio, com os diversos imaginários que lhe estão subjacentes, se dizem de múltiplos modos. Por outras palavras, e como vimos, os vários tipos de silêncio, e pensamos no silêncio interior como principal categoria que subsume aqueles por nós tratados, alimentam-se de poderosas imagens que não se confinam aos imaginários da montanha e do deserto, mas que clamam por outros imaginários tratados pela autora, tais como o voo dos pássaros, a ilha, a floresta, o mergulho nas profundezas do silêncio e o silêncio como um buraco negro, sem que esta soubesse compreendêlos numa unidade criadora.

Aquilo que realmente importa é interrogarmo-nos sobre o que une criativamente os vários imaginários tratados, particularmente os imaginários do deserto e da montanha. Num primeiro momento, poderemos dizer que aquilo que, por um lado, os une é o próprio silêncio no seu clamor pela liberdade indefinida e que, por outro lado, do ponto de vista simbólico, salientamos que ambos os imaginários se inscrevem no regime diurno do imaginário marcado miticamente 
pelo deus Apolo, que é um deus solar, racional e patriarcal, além das figura míticas de Hércules e de Prometeu estarem igualmente presentes. As caraterísticas deste regime, como regime da antítese e da distinção, apontam para os ideais de purificação, de claridade, da separação, da subida, do heroísmo, da luz e do ar, do angelismo - é o regime dos pássaros, das armas, do sol, etc (DURAND, 1984, p. 67215, p. 506-507).

No entanto, como o dissemos, é possível a mesma pessoa conciliar o silêncio religioso (místico) e romântico (criativo) cujos imaginários no seu significado mítico-simbólico apontam basicamente no mesmo sentido, ou seja, confluem para o mesmo regime - o diurno. Expliquemo-nos: o silêncio romântico carateriza-se pela solidão ascensional (montanha-ar-fluidez), e o silêncio religioso pela solidão íntima da terra fervente como túmulo escavado na rocha (deserto-terra-ascetismo). Importa, assim, sublinhar que aqui os pares terra-repouso (BACHELARD, 1986) e ar-movimento (BACHELARD, 2004) inscrevem-se no regime diurno do imaginário com as caraterísticas anteriormente mencionadas. Mas, aquilo que realmente importa é não perder a perspetiva da unidade dos dois silêncios no seio da sua própria diversidade, ou seja, devemos olhar as árvores sem contudo perder o sentido da floresta para usarmos aqui uma metáfora vegetal ou hortícola.

Deste modo, perguntamo-nos qual é o tipo de silêncio que se esconde na dialética dos silêncios religioso e romântico? Parece-nos bem que da sua vivência fusional no seio da mesma pessoa haverá lugar para uma espécie de terceiro incluído. Sara Maitland tem razão quando ela procura integrar na sua experiência de vida reflexiva o silêncio religioso, aquele dos Padres do deserto (busca o esvaziamento da personalidade e o silêncio pela oração) e o silêncio romântico, o dos escritores e poetas (buscando a criatividade pela literatura e pela poesia, embora não fique bem claro o modo como o deseja fazer. Todavia, e este aspeto já é para nós importante, a autora não caiu na armadilha de separar aquilo que nasceu para ser ou ficar unido. Porém, o tipo de silêncio resultante dessa integração (leiase fusão) já nos parece ser uma outra entidade, isto é, uma espécie de silêncio oximoro (lembrando o deus romano Janus), e, por isso, complexo na sua essência. 
Complexo porque vivificador de uma síntese criadora de duas naturezas diferentes de silêncio mas que, no entanto, encontram a sua unidade para além da sua aparente diferença: diferentes na forma, mas comungando de um mesmo silêncio que é aquele que identificamos com o silêncio interior.

Assim, mais do que denominar o silêncio que resulta da fusão dos dois silêncios - o religioso e o romântico - importa dele ter consciência fina para melhor o apreender e vivê-lo. Além disso, é um tipo de silêncio passível de ser contaminado por outras experiências de silêncio, tais como a do voo, das ilhas, da floresta, além do silêncio mediado pelas metáforas do "mergulho nas profundezas do silêncio" e "do silêncio como um buraco negro". Neste contexto, podemos sempre alinhar, por um lado, o silêncio da montanha (ar) com o tema e a imagem do voo, até mesmo da ilha onde o vento está omnipresente e, por outro lado, alinhar o silêncio do deserto com o silêncio vivido na floresta e as demais metáforas citadas, ainda que sem, e sublinhamos, nunca perder o sentido da unidade.

Agora, aquilo que mais nos importa é questionarmo-nos sobre a dúvida e a interrogação vivida por Sara Maitland sobre a tensão existente entre o silêncio espiritual de tipo religioso-eremítico (vivido e experienciado no deserto) e o silêncio criativo próprio da tradição romântica (vivido e experienciado na montanha), e se ela, em última instância, conseguiria no futuro integrá-los, ou fundi-los, na sua personalidade. Por outras palavras, pretendemos saber se ela consegue ou é capaz de viver o silêncio religioso de tipo eremítico (o lado obscuro do silêncio), comparado com um "mergulho nas profundezas" e com "um buraco negro", sem abrir mão daquilo que ela identificou com o silêncio romântico, criativo, e que lhe permite, por sua vez, ser a escritora que ela é e que quer continuar a ser.

Sara Maitland, depois de recensear outro tipo de silêncios (MAITLAND, 2011, p. 373-374) (as suas palavras são válidas para o binómio silêncio religiososilêncio romântico) escreve que esse tipo de silêncios 
são vividos como integradores; toda a personalidade está envolvida e é conhecida de si mesma, de uma forma nova. Ainda mais comum e profunda é a falta de delimitação - as pessoas sentem que estão de fora, observando-se a si mesmas, 'posicionadas a grande altura', mas sem qualquer sensação de separação ou divisão. Uma noção da diferença entre a Personalidade e o Outro, entre o Eu e o Tu torna-se pouco clara - com exceção do facto de não haver perda de integridade. É normalmente a reafirmação do ego, da auto-consciência, que põe fim a este estado. (MAITLAND, 2011, p. 375).

O sentimento que, segundo a autora, resulta desta integração é o da "inefabilidade" (MAITLAND, 2011, p. 375). Do exposto, depreende-se que ela admite francamente a possibilidade de essa fusão acontecer e dela tem profunda consciência. No entanto, desta consciência não resulta necessariamente que Sara Maitland consiga aceder plenamente ao estado de fusão ou de integração tão desejada, e ela própria o admite quando escreve:

Acho difícil terminar este livro, porque não me parece ter chegado ao final de nada. Em Warkton, lá bem no princípio, tentei criar um jardim que se abrisse para o infinito, que renunciasse à satisfação do fecho, na esperança de descobrir a jouissance daquilo que não foi resolvido, do que mantém o final em aberto. Agora estou a tentar criar toda uma vida que permita concretizar isso. Para mim, o silêncio é simultaneamente um instrumento e o conteúdo dessa vida. (MAITLAND, 2011, p. 386).

É um desejo forte que, a nosso ver, parece dignificar, redentarizar e envolver comprometidamente a personalidade da autora. No entanto, interrogamo-nos sobre o facto de Sara Maitland, mesmo no final da sua obra, encarar, ainda que, metaforicamente, o silêncio como um buraco negro (MAITLAND, 2011, p. 385386). Esta abordagem introduz o tema de Deus e, por extensão, introduz o tema do silêncio religioso, mesmo místico. Por outras palavras, aquilo que pretendemos salientar é que nos parece que Sara Maitland se sente mais tocada e interpelada pelo silêncio religioso, espiritual, do que pelo silêncio criativo, ainda que à primeira vista tal possa parecer paradoxal. Mas se olharmos mais de perto a sua obra, mais particularmente o último capítulo, intitulado: A Chegada a Casa (MAITLAND, 2011, p. 347-386), notamos que a sua vivência religiosa e consequente comunhão com Deus foi marcadamente visível e comprometida: "Rezo três horas por dia; $\mathrm{Na}$ verdade, faço-o por mim própria, mas também rezo por outros e para que o meu silêncio possa ser útil de alguma forma no mundo barulhento em que vivemos" 
(MAITLAND, 2011, p. 372). Nesta linha, basta pensarmos também na passagem em que ela fala, ainda que num registo metafórico, no "mergulho" nas "profundezas" do silêncio (MAITLAND, 2011, p. 379-380). O salto no buraco negro do silêncio insondável e misterioso, que faz fronteira com o tremendo nada, ainda que cálido, assusta e é perturbador, mesmo para uma personalidade espiritual como a de Sara Maitland: "Não me sinto preocupada por cair da borda de um abismo sem fundo, tenho antes a sensação de subir um nível, de ascender a um ar mais limpo e mais saudável” (MAITLAND, 2011, p. 386). As profundezas desconhecidas sempre assustaram porque elas tendem aqui a encarnar a presença do Ser na sua plenitude, que é insuportável para os postulantes, mesmo para os noviços (iniciantes), mas que é redentor para os iniciados, à semelhança de Parsifal que, depois de tantas provações, foi digno de contemplar a luz do Santo Graal. Deste modo, se é verdade que Sara Maitland não é mais uma noviça na senda do colapso do tempo e do espaço que o silêncio engendra, não é menos verdade que enquanto ela enfrentar o terror e o risco que envolvem o silêncio as portas da iniciação continuar-lhe-ão abertas em direção ao Silêncio como Graal!

\section{Conclusão}

Recordando que o nosso estudo visava compreender o imaginário do silêncio, tendo como base a obra de Sara Maitland O Livro do Silêncio ( $A$ Book of Silence), procuramos compreender na primeira parte, dedicada à natureza do silêncio, as suas manifestações e os seus diferentes tipos. O silêncio, enquanto experiência espiritual multifacetada, misteriosa, complexa e profunda, diz-se fundamentalmente de dois modos distintos: um ligado à oração, que corresponde à tradição dos Padres do deserto (séculos III e VI), e outro ligado ao ato artístico de criação correspondendo à tradição romântica (MAITLAND, 2011, p. 262, p. 302 e p. 316).

Na segunda parte ocupamo-nos do "imaginário do silêncio" que nos foi oferecido por Sara Maitland no seu capítulo intitulado "Lugares de Silêncio" (p. 211-256). Nesta parte, procuramos traçar uma tipologia do imaginário do silêncio, 
ou seja, procuramos fazer uma radiografia do silêncio do ponto de vista do imaginário e o resultado revelou-se deveras surpreendente pelo facto de dizer-se imaginário através do voo, das ilhas, da floresta, do deserto, da montanha, do mergulho nas suas profundezas e, por fim, se diz como um buraco negro. É, no entanto, através do imaginário do deserto e da montanha que o silêncio, de acordo com as experiências da autora, melhor se exprime, porquanto Sara Maitland elege, como já vimos, o silêncio eremítico ou religioso como aquele que é próprio do deserto, enquanto o silêncio romântico está ligado à montanha. Se ambos os silêncios se diferenciam no plano espiritual, psicológico e cultural, do ponto de vista do imaginário ambos se filiam ao regime diurno do imaginário com as caraterísticas que lhe são próprias, sem esquecer o silêncio como "mergulho nas suas profundezas”, associado ao regime noturno do imaginário.

A nossa terceira parte, intitulada: "Silêncio, Imaginário e Criatividade", visa compreender como a autora pretendia integrar os silêncios espiritual e criativo. $\mathrm{O}$ que pretendemos dizer é que a autora procurava, através do silêncio espiritual ou religioso, estreitar e aprofundar a sua união com Deus e, através do silêncio criativo, criar literatura. Ela diz que, para sua satisfação, tinha identificado esses dois géneros diferentes de silêncio e que os continuava a querer (MAITLAND, 2011, p. 347). Em síntese, ela queria concretizá-los em si de modo vivencial: "Ambicionava ser, em simultâneo, uma pessoa que habitava no silêncio e uma escritora. Queria escrever silenciosamente... escrever em silêncio. Não sabia como isso poderia ser feito, nem sequer se poderia ser feito, mas queria muito tentar descobrir" (MAITLAND, 2011, p. 349-350). Eis a sua missão depois de "Chegada a casa" (Cap. 8, p. 347-386) - descobrir se poderia "escrever [criativamente, solitariamente] em silêncio [recolhidamente e em união com Deus]”. Admitindo a possibilidade de o conseguir, discutimos a relação da trilogia "silêncio-imagináriocriatividade", na qual, entre outros aspetos, nos interrogamos, por um lado, sobre a fusão entre o silêncio religioso e romântico e o tipo de silêncio que dela brota, e, por outro, do tipo de imaginário que dá conta dessa fusão. 
Para terminarmos, e resumindo a nossa posição, dizemos que a fusão entre o silêncio religioso e o romântico acontece, por um lado, tematicamente sob o regime do oximoro, do terceiro incluído e da coincidentia oppositorum e, por outro lado, acontece prevalentemente sob o regime simbólico do regime diurno e, miticamente, sob o signo do deus romano Janus. Se aceitamos a possibilidade de Sara Maitland integrar e con-viver com ambos os silêncios tal integração não se faz, contudo, num equilíbrio estático, mas antes em tensão dinâmica, donde é passível brotar uma criatividade iluminante dos pontos de vista da alta espiritualidade e da própria escrita do romance ou poética. Do ponto de vista da natureza do imaginário que dá conta dessa fusão, embora seja marcado basicamente pelo regime diurno do imaginário, não podemos, contudo, descurar o imaginário noturno com os símbolos e metáforas que lhe estão naturalmente associados. Neste sentido, ganham especial destaque os imaginários da ilha, da floresta e as metáforas do “mergulho nas profundezas do silêncio" e "do silêncio como um buraco negro". E assim, podemos afirmar que a vivência do silêncio por parte de Sara Maitland não pode escapar ao apelo, que não é indiferente, do regime noturno, marcado pela síntese e pelo verbo con-fundir.

\section{REFERÊNCIAS}

BACHELARD, Gaston. L'air et les songes: sur l'imagination du mouvement. Paris: Librairie José Corti/Le Livre de Poche, 2004.

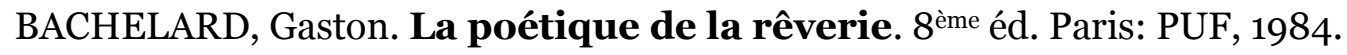

BACHELARD, Gaston. La terre et les rêveries du repos. $14{ }^{\text {ème }}$ Réimp. Paris: Librairire José Corti, 1986.

BERLIN, Iasaiah. As raízes do Romantismo. Trad. de Isa Mara Lando. São Paulo: Três Estrelas, 2015 .

BIEDERMANN, Hans. Encyclopédie des symboles. Trad. de François Périgaut, Gisèle Marie et Alexandra Tondat. Paris: Librairie Générale Française/La Pochothèque, 1996.

BUCKLEY, Martin. Grains of sand. London: Vintage Publishing, 2001. 
CHEVALIER, Jean; GHEERBRANT, Alain. Dicionário dos símbolos. Trad. de Cristina Rodriguez e Artur Guerra. Lisboa: Editorial Teorema, 1994.

CIRLOT, Juan Eduardo. Diccionario de símbolos. 4. ed. Madrid: Ediciones Siruela, 2000.

CORBIN, Alain. Histoire du silence. De la Renaissance à nos jours. Paris : Albin Michel, 2016.

DIEL, Paul. Le symbolisme dans la mythologie grecque. Paris: Payot, 1989.

DURAND, Gilbert. Les structures anthropologiques de l'imaginaire. Introduction à l'archétypologie générale. 10. éd. Paris: Dunod, 1984.

ELIADE, Mircea. Tratado de História das Religiões. Trad. de Fernando Tomaz e de Natália Nunes. 2. ed. Porto: Edições Asa, 1994.

GUSDORF, Georges. Le Romantisme: le savoir romantique. Paris. Payot \& Rivages, 1993. v. 1.

GUSDORF, Georges. Le Romantisme: l' homme et la nature. Paris. Payot \& Rivages, 1993. v. 2.

MAFFESOLI, Michel. La parole du silence. Paris : Les Editions du Cerf, 2016.

MAITLAND, Sara. O livro do silêncio. Trad. de Jorge Almeida e Pinho. Alfragide. Estrela Polar, 2011.

SARAH, Robert (Cardinal) ; DIAT Nicolas (avec). La force du silence: contre la dictature du bruit. Paris: Fayard, 2016.

WADELL, Helen. The Desert Fathers. Translated and Introduction by Helen Wadell. London: Vintage Spiritual Classics Original, 1998. 